International Journal of Social Science and Economic Research

ISSN: 2455-8834

Volume:06, Issue:07 "July 2021"

\title{
ROLE OF WOMEN IN DETERMINING THE HEALTH STATUS OF MANIPUR
}

\author{
Kshetrimayum Rabikan Singh \\ Assistant Professor, Department of Economics, Arignar Anna Govt. Arts and Science College, Karaikal, \\ Govt. of Puducherry
}

DOI: 10.46609/IJSSER.2021.v06i07.030 URL: https://doi.org/10.46609/IJSSER.2021.v06i07.030

\begin{abstract}
Manipur has $2^{\text {nd }}$ largest below poverty line population $(46.7 \%)$ and is ranked $3^{\text {rd }}$ lowest per capita income among all the states in India. Despite being one of the poorest states in India, her achievements in many aspects of the health are worth laudable. The present study attempts to understand the health achievements of Manipur by exploring the factor of women empowerment using the secondary data NHFS 4, 2015-16. The study reveals that Manipur is one of the best five performers among all the states in many of the important health indicators, such as wasting, underweight, anaemia, infant mortality rate, under five mortality rates and BMI. This fact implies that the differences in health achievements between different states could not be a matter of per capita income or income poverty alone. The study finds that women empowerment seemed to play a crucial role in Manipur`s astonishing achievements. For instance, women`s participation in household decision making $(96.2 \%)$ and labour force $(40.9 \%)$, women`s literacy rate $(85 \%)$, women owning house/land $(69.9 \%)$ are among the top five performers in India. Therefore, understanding the role of women seemed to be a key factor in determining the Manipur`s health achievements.
\end{abstract}

Keywords: Women Empowerment, Health status, Manipur, Health Achievements.

\section{Introduction}

Manipur despite being one of the poorest states in India, her achievements in many aspects of the health are worth laudable. Manipur stands at the bottom of poverty and per capita income rankings. Manipur has the 2nd largest poverty(C Rangaranjan committee, 2014) and $3^{\text {rd }}$ lowest per capita income (RBI handbook of statistics 2016-17) among the states of India. The socio economic condition got even worse due to various ethnic conflicts, AFSPA, Economic Blockage throughout the year. However, Manipur is one of the best five performers among all the states in many of the health indicators. 


\section{International Journal of Social Science and Economic Research}

ISSN: $2455-8834$

Volume:06, Issue:07 "July 2021"

Despite having an impressive economic growth, the health condition of India is still among the worst in the world. Dreze and Sen (2013) argue that the impressive economic growth in India does not lead to proportionate improvement in social development, especially not in health. Ex. Prime Minister Manmohan Singh expressed his disappointment in health development, saying, "We cannot hope for a healthy future for our country with a large number of malnourished children"i. It is not the end, there are more than 620 million people practicing open defecation in the country; over 50 percent of the total population (UNICEF and WHO, 2012). Lack of proper sanitation and clean drinking water are the major cause of communicable disease. The burden of communicable diseases is among the highest in the globe. India has the highest population of TB cases. Out of 9.2 million cases of TB occur in India every year, India`s share is nearly 1.9 million which accounted for one fifth if the global TB cases (Cauhan, 2011).

The nutritional status of India, for both children and adult, are also one of the lowest in the world. Deaton and Dreze (2009) claim that the under-nutrition in India remains higher than those many countries of Sub Saharan Africa, even though India is richer country than those countries. The Economic magazine its article 'Putting the smallest First' noted that Nearly half of India's small children are malnourished: one of the highest rate of underweight children in the world, higher than most countries in the Sub Saharan Africa. More than one third undernourished children lives in India. Manmohan Singh was right to recognize the grave situation, who went on to lament, "the problem of malnutrition is a matter of national shame. Despite impressive growth in our GDP, the level of under-nutrition in the country is unacceptably high. We have also not succeeded in reducing this rate fast enough".

Within India, regional diversity or regional contrast in terms of health development and achievements had also been observed in many studies. States such as Kerala, Goa, Tamil Nadu, Manipur had significant health achievements as compared to states in Northern heartland. Many studies have been done in high achievers states like Kerala and Tamil Nadu, as well as low performers like Bihar and UP. Dreze and Sen (2002) identify the extensive links between Kerala`s outstanding social achievements especially in health and education and its rich history of public action. Though Kerala have been quite modest in generating economic growth, the role of state in providing health and education is quite outstanding. Other studies also claimed the importance of role played by state in Kerala`s social achievements ( V. K. Ramachandran, 1996). Role of women agency and women empowerment in Kerala`s social acheivment is also widely recognized ( Dreze and Sen (2002)). For instance, Dreze and Sen(2002) relate remarkably high life-expectancy levels in Kerala to educational achievements of Women while relatively low expectancy levels in northern India is credited to backwardness in female education. Another state, which state play a key role in improving social achievement, is Tamil Nadu. 
Therefore, various factors besides income, such as women empowerment, public health, role of state could be the determining factors for development in health. It is within this context the present study attempts to understand the exceptional health achievements of Manipur despite being a poverty ridden state. It intends to analyse Manipur`s health achievements so that lessons could be learned for other states.

\section{Data Sources and Methodology}

The study is primarily based on secondary data from NHFS-4, 2015-16 and it also uses other secondary sources like government committee report, articles and magazines. Simple tabulations and descriptive analysis have been used for the purpose of the analysis.

\section{Health Achievements in Manipur}

Manipur despite being a state of problems and conflicts, manage to achieve commendable health outcomes. As per Niti Ayog`s Healthy States Progressive India 2018, Manipur ranked first in terms of annual incremental performance and second in overall performance among the smaller states.

Fig 1.1 shows a positive association the between infant mortality rate and poverty rates across 28 states in India. For instance, States with high poverty rates such as Chattisgarh, Odisha, Uttar Pradesh, Madhya Pradesh and Bihar have high infant mortality rate while higher income states like Goa, Kerala, Punjab and Haryana have low infant mortality rate.

However, one exceptional case is that Manipur, despite having $2^{\text {nd }}$ largest poverty, infant 
International Journal of Social Science and Economic Research

ISSN: 2455-8834

Volume:06, Issue:07 "July 2021"

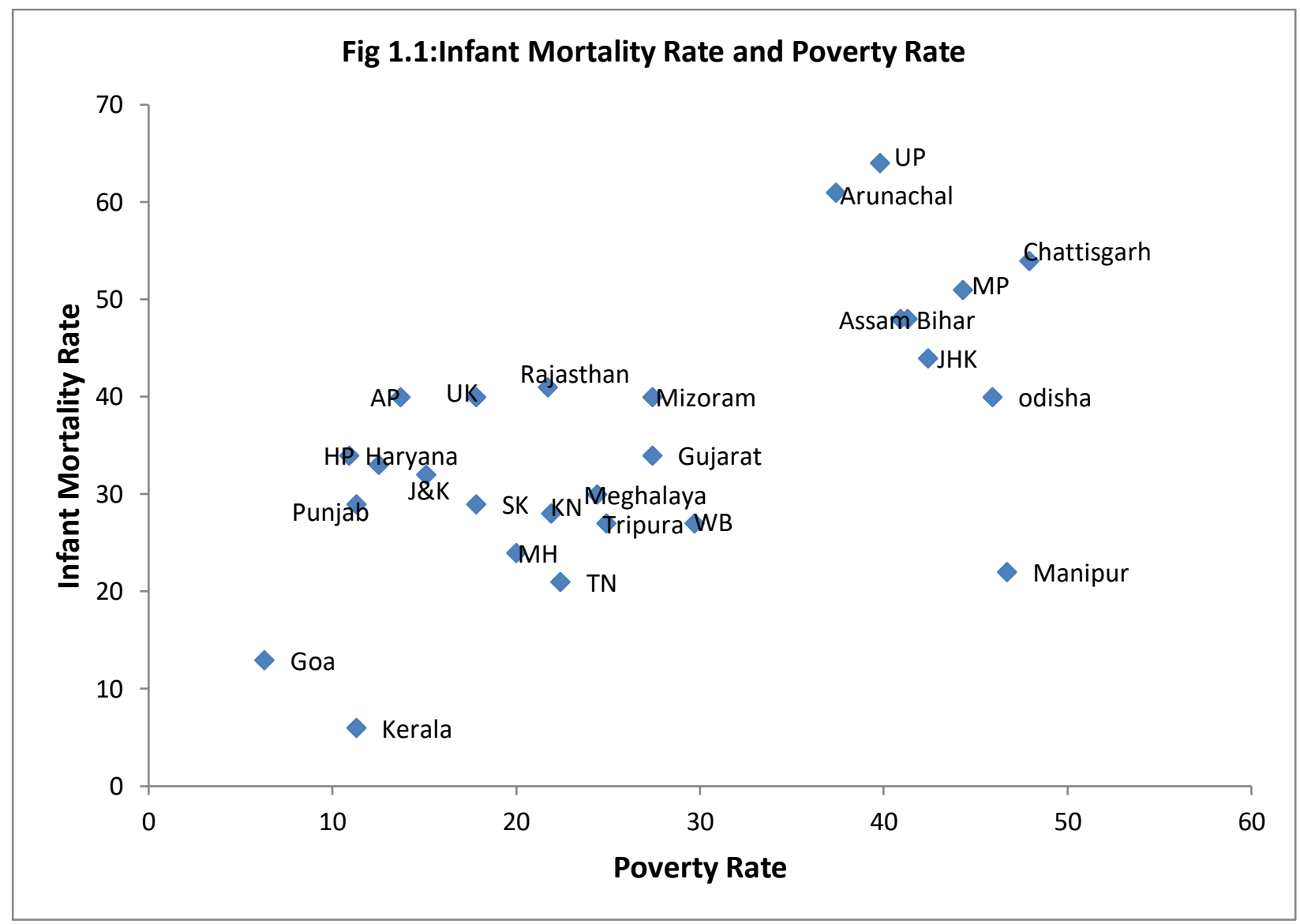

Sources: C Rangarajan Working Committee Report on Poverty, 2014 and NHFS 2015-17.

mortality rate in the state is very low, even comparable to Kerala and Goa. Manipur even has lower infant mortality rate than higher income states such as Punjab, Haryana, Sikkim and Andhar Pradesh. Therefore, other factors besides income poverty could be involved in determining the health achievements of Manipur. This need not mean that income has no impact on the infant mortality rate.

Further, Fig 1.2 and Fig 1.3 are plotted to observe the relationship between infant mortality rates against per capita Net State Domestic Product for 27 states in India ${ }^{\text {ii }}$. 
International Journal of Social Science and Economic Research

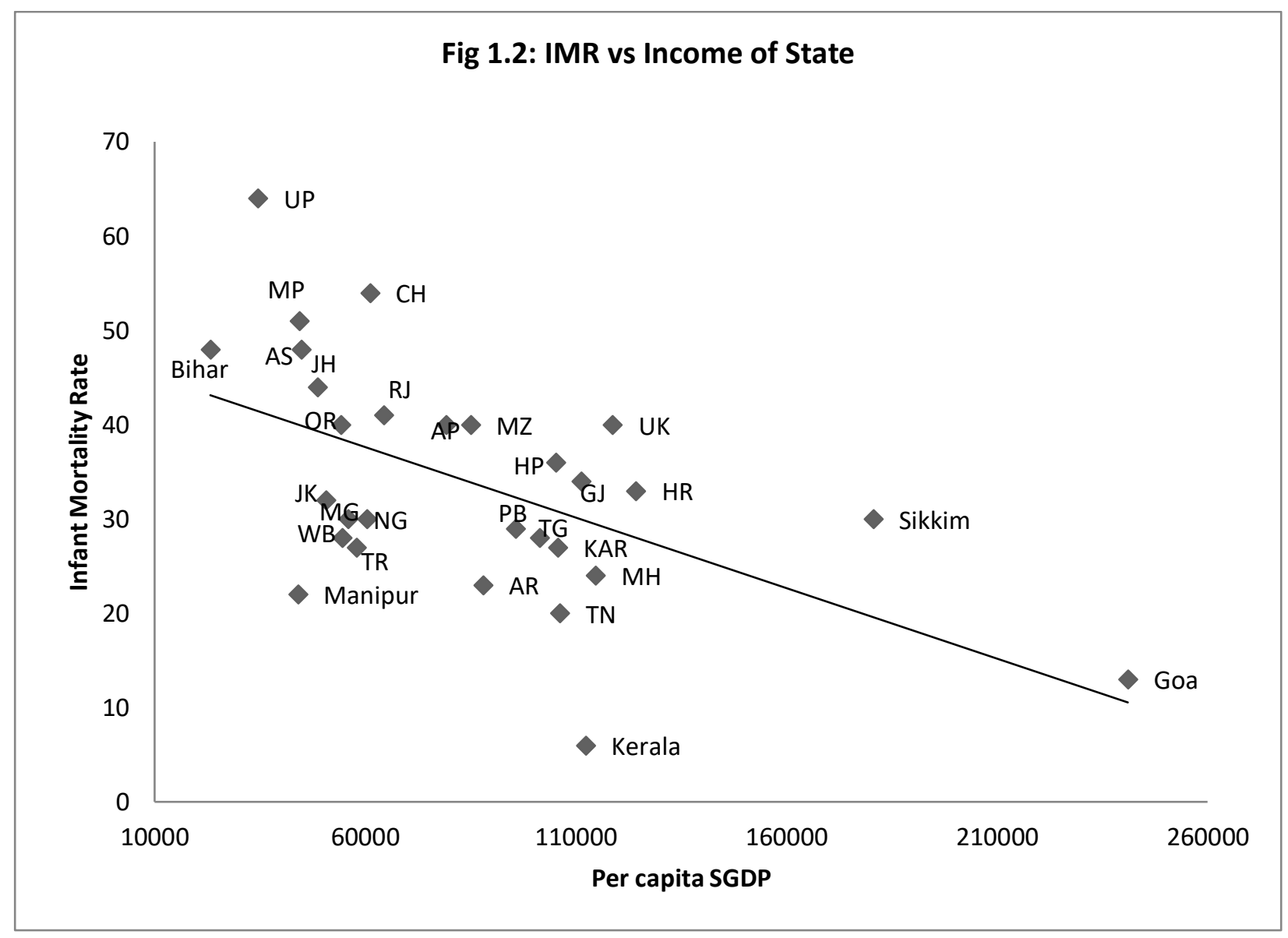

Sources: NHFS 4, 2015-16 and RBI Handbook of Statatics, 2016-17

The figures show a broad negative relationship between per capita income and infant mortality rate, indicating lower infant mortality for higher per capita income states. However, Manipur despite having $3^{\text {rd }}$ lowest per capita income, infant mortality rate in the state is $4^{\text {th }}$ lowest among the 27 states in India. Though per capita income seems to play a role in determining infant mortality rate among the states in India, it is less important in case of Manipur. 
International Journal of Social Science and Economic Research

ISSN: 2455-8834

Volume:06, Issue:07 "July 2021"

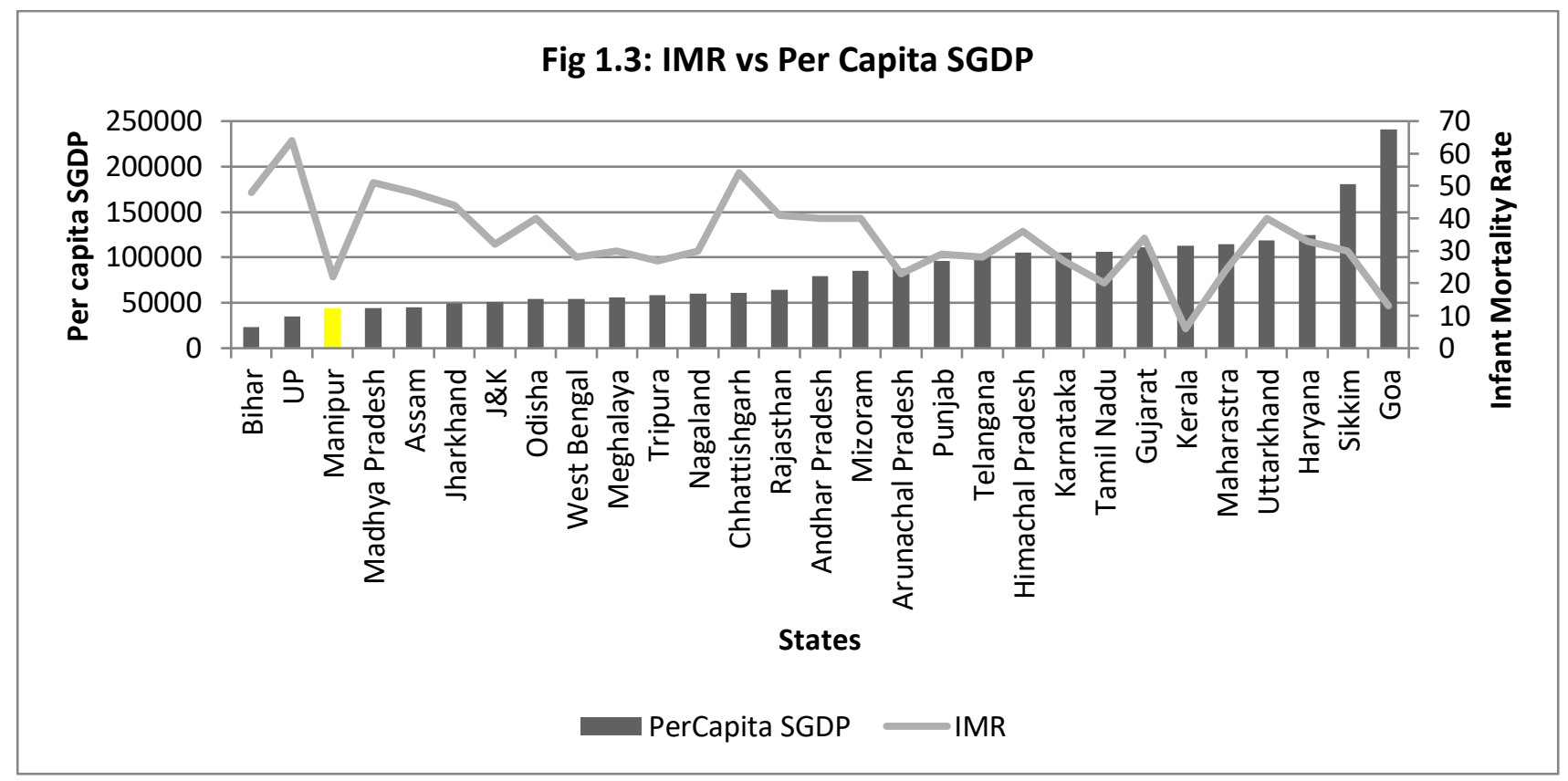

Sources: NHFS 4, 2015-16 and RBI Handbook of Statatics, 2016-17

Further, a table which shows the top five performers in key health indicators is created to gain some insights on the relationship between per capita income and key health indicators (See table 1.1). Number in the brackets show the ranking of the states based on per capita income. Though there is less striking pattern, the top 5 performers are all high income or middle income states except Manipur which is $26^{\text {th }}$ poorest state in India.

Table 1.1: Best Five Performers in key health indicators and Per Capita Income Ranks

\begin{tabular}{|c|c|c|c|c|c|c|c|}
\hline IMR & U5MR & Stunted & Wasted & Underweight & $\begin{array}{l}\text { Anaemic } \\
\text { Children }\end{array}$ & $\begin{array}{l}\text { Anaemic } \\
\text { Women }\end{array}$ & $\begin{array}{l}\text { BMI }<18.5 \\
\text { (Thin) }\end{array}$ \\
\hline $\begin{array}{l}\text { Kerala } \\
\text { (4) }\end{array}$ & $\begin{array}{l}\text { Kerala } \\
\text { (4) }\end{array}$ & $\begin{array}{l}\text { Kerala } \\
(4)\end{array}$ & $\begin{array}{l}\text { Mizoram } \\
\text { (14) }\end{array}$ & $\begin{array}{l}\text { Manipur } \\
(26)\end{array}$ & $\begin{array}{l}\text { Mizoram } \\
\text { (14) }\end{array}$ & $\begin{array}{l}\text { Mizoram } \\
\text { (14) }\end{array}$ & $\begin{array}{l}\text { Sikkim } \\
(2)\end{array}$ \\
\hline $\begin{array}{l}\text { Goa } \\
\text { (1) }\end{array}$ & $\begin{array}{l}\text { Goa } \\
(1)\end{array}$ & $\begin{array}{l}\text { Goa } \\
\text { (1) }\end{array}$ & $\begin{array}{l}\text { Manipur } \\
(26)\end{array}$ & $\begin{array}{l}\text { Sikkim } \\
(2)\end{array}$ & $\begin{array}{l}\text { Nagaland } \\
\text { (15) }\end{array}$ & $\begin{array}{l}\text { Nagaland } \\
\text { (15) }\end{array}$ & $\begin{array}{l}\text { Mizoram } \\
\text { (14) }\end{array}$ \\
\hline $\begin{array}{l}\text { Tamil Nadu } \\
\text { (8) }\end{array}$ & $\begin{array}{l}\text { Manipur } \\
\text { (26) }\end{array}$ & $\begin{array}{l}\text { Tripura } \\
\text { (19) }\end{array}$ & $\begin{array}{l}\text { Nagaland } \\
\text { (15) }\end{array}$ & $\begin{array}{l}\text { Mizoram } \\
\text { (14) }\end{array}$ & $\begin{array}{l}\text { Manipur } \\
\text { (26) }\end{array}$ & $\begin{array}{l}\text { Manipur } \\
\text { (26) }\end{array}$ & $\begin{array}{l}\text { Arunachal } \\
\text { Pradesh } \\
\text { (12) }\end{array}$ \\
\hline $\begin{array}{l}\text { Manipur } \\
(26)\end{array}$ & $\begin{array}{l}\text { Tamil Nadu } \\
\text { (8) }\end{array}$ & $\begin{array}{l}\text { Punjab } \\
\text { (11) }\end{array}$ & $\begin{array}{l}J \& K \\
(22)\end{array}$ & $\begin{array}{l}\text { Kerala } \\
(4)\end{array}$ & $\begin{array}{l}\text { Kerala } \\
(4)\end{array}$ & $\begin{array}{l}\text { Goa } \\
(1)\end{array}$ & $\begin{array}{l}\text { Manipur } \\
(26)\end{array}$ \\
\hline $\begin{array}{l}\text { Maharastra } \\
\text { (6) }\end{array}$ & $\begin{array}{l}\text { Maharastra } \\
\text { (6) }\end{array}$ & $\begin{array}{l}\text { Himachal } \\
\text { Pradesh } \\
\text { (10) }\end{array}$ & $\begin{array}{l}\text { Himachal } \\
\text { Pradesh } \\
(10)\end{array}$ & $\begin{array}{l}J \& K \\
(22)\end{array}$ & $\begin{array}{l}\text { Assam } \\
(25)\end{array}$ & $\begin{array}{l}\text { Kerala } \\
\text { (4) }\end{array}$ & $\begin{array}{l}\text { Kerala } \\
\text { (4) }\end{array}$ \\
\hline
\end{tabular}

Sources: NHFS 4, 2015-16 and RBI Handbook of Statatics, 2016-17 


\section{International Journal of Social Science and Economic Research}

ISSN: $2455-8834$

Volume:06, Issue:07 "July 2021"

Manipur is among the top 5 performers in 7 out of 8 key health indicators. These reaffirm the proposition that income alone is not the factor for enhancing health conditions. Dreze and Sen (2013) also mentioned the fact that India is also falling behind every other South Asian country except Pakistan in terms of many social indicators, even as it is doing spectacularly better than these countries in terms of growth of per capita income. For instance, Bangladesh despite having almost half the per capita income of India, she has overtaken India in terms of basic health indicators such as life expectancy, child survival, reduced fertility rate and enhanced immunization rate. Dreze and Sen (2013) despite acknowledging not clear or transparent roots of Bangladesh`s social achievements, they give credits to positive change in gender relations. Women empowerment seemed to play a key role in Bangladesh astonishing achievements. For instance, women`s work participation rate in Bangladesh is almost twice as high in India (59 percent and 29 percent respectively), greater female literacy than India. Bangladesh also made remarkable achievements towards gender equality, such as school participation rates and literacy rates of girls are higher than those of boys. Even the share of women in Parliament is higher in Bangladesh than in India. ${ }^{\text {iii }}$ Key roles performed by women`s agency such as front-line health workers are also acknowledged by the authors.

\section{Understanding the Manipur`s Health Achievements}

In order to find the roots of Manipur`s paradox, it has to be focus on various determining factors of health such as women empowerment, public health and health care system. Various studies have proved the positive association between women empowerment and health status. Varky $\mathrm{P}$ et al (2010) in their study across 75 countries, using human development reports data, found that empowerment of women i.e Gender Empowerment Measurement(GEM) has proven to lower fertility rate and improves child and found to have negative relationship with maternal mortality rate and positive association with life expectancy rate. Bhagwati et al (2012) also find enhanced women decision making power and mobility reduced child stunting in their study in Bangladesh. Maternal autonomy found to have positive association with infant feeding in Andhra Pradesh (Shroff et al. 2011). Chaudhury at al (2012) and Dreze and Sen(2013) emphasis the role of women agency for the exceptional health achievement in Bangladesh despite its high economic poverty.

Another important factor which could have remarkable impact on health is the progress on public health. Besides women's empowerment factor, achievement in public health is also a key determinant for Bangladesh health achievements. Table 1.2 presents some selected public health indicators in India and Bangladesh. In all the selected indicators, Bangladesh achievements are much better than India. For instance, $55 \%$ of Indian population practiced 'open defecation' while only $8.4 \%$ have to resort to 'open defecation' in Bangladesh. Bangladesh achievements in 


\section{International Journal of Social Science and Economic Research}

ISSN: $2455-8834$

Volume:06, Issue:07 "July 2021"

sanitation are remarkable. The contrast between these two countries in public health is very sharp.

Monica Das Gupta (2005) also argues that India`s health policies are largely focused on medical services and public health services are neglected. Public health services are conceptually distinct from medical services. Public health services are preventive measures and its key goal is to reduce exposure to disease such as vector control, monitoring waste disposal and water systems and health education to improve health behaviours and build citizen demand for better health outcomes $^{\text {iv }}$. Therefore, there have been many evidences which validate that income is not the only factor which can influence health outcomes. Other important factors relevant to health achievements are women empowerment, public health and role of state. The present study especially focus on role of women in determining the Manipur`s health achievements.

Table 1.2

India and Bangladesh: Selected Indicators of Public Health

\begin{tabular}{|l|c|c|}
\hline & India (2005-6) & Bangladesh(2007) \\
\hline Proportion of households practicing open defecation & $55 \%$ & $8.4 \%$ \\
\hline $\begin{array}{l}\text { Proportion of children aged 12-23 months who fully } \\
\text { immunized }\end{array}$ & $44 \%$ & $82 \%$ \\
\hline $\begin{array}{l}\text { Proportion of the population with sustainable access } \\
\text { to an improved water sources }\end{array}$ & $88 \%$ & $88 \%$ \\
\hline $\begin{array}{l}\text { Proportion of children aged 9-59 months who } \\
\text { received Vitamin A supplements }\end{array}$ & $55 \%$ & $89 \%$ \\
\hline $\begin{array}{l}\text { Proportion of children who started breastfeeding } \\
\text { within 24 hours of birth }\end{array}$ & $39 \%$ & $81 \%$ \\
\hline $\begin{array}{l}\text { Proportion of diarrhea-affected children treated with } \\
\text { oral rehydration therapy' }\end{array}$ & $18 \%$ & \\
\hline
\end{tabular}

Sources: Dreze and Sen (2013), Table 3.6, pp 63

Monica Das Gupta (2005) also argues that India`s health policies are largely focused on medical services and public health services are neglected. Public health services are conceptually distinct from medical services. Public health services are preventive measures and its key goal is to reduce exposure to disease such as vector control, monitoring waste disposal and water systems and health education to improve health behaviours and build citizen demand for better health outcomes ${ }^{\mathrm{v}}$. Therefore, there have been many evidences which validate that income is not the only factor which can influence health outcomes. Other important factors relevant to health achievements are women empowerment, public health and role of state. The present study 


\section{International Journal of Social Science and Economic Research}

ISSN: $2455-8834$

Volume:06, Issue:07 "July 2021"

especially focus on role of women empowerment and public health system in determining the Manipur`s health achievements.

\section{Women`s role in Manipur development: a historical perspective}

This section attempts to look at women`s position in Manipur through a socio-economic analysis. From Nupi Lal ( Women`s War) to Nisha Bandhi (anti-alcoholism movement) and Maira paibi (Flaming Torches holder), women in Manipur have always actively engaged in social, political and economic issues since colonial period. It was them who stood against British and colonialism in 1904 and 1939. These two wars, Nupi Lal I (1904) and Nupi Lal II (1939) were literally 'women wars' rebelled against the British. These massive women's movements were a collective fight against political injustice during the colonial rule.

There is inherent tradition of collective womanpower in the society, for any social ills. Scholars have acknowledged the prominence of women as powerful dissenting figures in Manipur. "The ancient and medieval period of folk oral literature of Manipuri language was the literature of protest. The protagonist was always a women....the nucleus of female power in the group form is intact even today" (Arambam Ongbi Mamchoubi) ${ }^{\mathrm{vi}}$. Even after independence, the Nisha Bandhi movement took shape in 1970s against the rise in the sale of liquor and resulted menace such as wives beating, loss in income and lost lives. They raided local liquor vends and set fire to alcohol supplies. Because they move around at night carrying flaming torches to check illegal consumption and sales of liquor, people informally refer them as 'Maira Paibis' which mean torches bearers. Maira Paibis and Nisha Bandhi are still very active and their movements, besides its core fight against drug addiction and alcoholism, have raised the issues of price rise, domestic violence and sexual abuse in recent years.

From 1980s onwards, Maira Paibis increasingly raised up issues related to military excess and militarization of state. They began focusing on military excessive atrocities on youth and man such as unwarranted arrest, fake encounter and beating of youth with no reason. So, the Manipuri women come out of the image of wives and mothers, turning into agents for various social functions. Importance of women's agency for social change is widely acknowledged by many authors ( Sen, A 1995, 2002, Kabeer, 1999). Kabeer perceived 'agency' as the ability to define one`s goals and act upon them. For instance, women`s ability to exercise decision making in iterpersonal level or public domain.

The economic contribution of women in the state is remarkable. Ema keithel (Mothers` market) took an important place in the day to day economic activity. Women's work participation rate is higher than the national average. Besides, they also actively engaged in many social groups such as Nupi Marup, Esei Marup and NGOs. 


\section{International Journal of Social Science and Economic Research}

ISSN: $2455-8834$

Volume:06, Issue:07 "July 2021"

G.K. Ghosh and Shukla Ghosh in their book, 'Women of Manipur' vii, argued that Position of women among various communities in Manipur is much better then rest of India not only because women are talented lot but because of the social fabric says so. They precisely blamed the outside influences, for women's subjugation in Manipur. Whatever deterioration that took place was because of influence from rest of India and abroad due to influence of various religions like Hinduism, Christianity and Islam besides imposition of cultural and economic trend $^{\text {viii }}$.

Another remarkable women`s position in Manipur is in relation to religious norms and cultures. For every local deities and forest gods, the rituals and prayers are performed by 'Maibas' i.e male priests and 'Maibis' i.e female priests. Maibas and Maibis took equal position in performing ritual fuctions of local deities and gods. This is in sharp contrast to Hindu Temple where there is pure dominant by male priests.

So, it seems that women in Manipur took a special status in the society; status refers to the value attached to women in a society. It is quite possible to have high status but less empowered functions. For instance, though Manipuri women are quite highly valued and given respect by the society, prevalence of domestic violence is quite high and they have heavier workload and less decision making power in relation to their husband. There is no denial of existence of gender inequalities in Manipur. The only intention here is that the prevalence of gender inequalities in Manipur seemed to be less as compared to the rest of India. They are given more independent and given more respect in comparison to mainland India. However, empowerment concept is not an end to itself, it is a continual process.

Keeping these background of women's position in Manipur, the study further compares the on some factors which could enhanced women empowerment across Indian states using the NHFS 4 data. Table 1.3 shows top six States where the sources of women empowerment are relatively better compared to the other States. Manipur is the only states which occupied a place in all the five sources of empowerment. Percentage of women owning land or house in Manipur is the highest in India (69.9\%), 96.2 percent of married women in Manipur usually participate in household decision making and work participation rate of women in Manipur is $3^{\text {rd }}$ highest among all the states. So, higher women empowerment level in Manipur could be an important determining factor for the Manipur`s paradox. However, micro studies are needed to proof any link with women empowerment and health outcomes. 
International Journal of Social Science and Economic Research

ISSN: 2455-8834

Volume:06, Issue:07 "July 2021"

Table 1.3: Sources of Women Empowerment

\begin{tabular}{|c|c|c|c|c|c|c|c|c|c|}
\hline \multicolumn{2}{|c|}{$\begin{array}{l}\text { Married women } \\
\text { who usually } \\
\text { participate in } \mathrm{HH} \\
\text { decision making }\end{array}$} & \multicolumn{2}{|c|}{$\begin{array}{c}\text { Percenatge of } \\
\text { Women who } \\
\text { worked in last } 12 \\
\text { months }\end{array}$} & \multicolumn{2}{|c|}{$\begin{array}{c}\text { Percentage of } \\
\text { Women owning } \\
\text { house or land }\end{array}$} & \multicolumn{2}{|c|}{$\begin{array}{c}\text { Proportion of } \\
\text { Women Literacy }\end{array}$} & \multicolumn{2}{|c|}{$\begin{array}{c}\text { Women } \\
\text { educated more } \\
\text { than } 10 \text { years or } \\
\text { more in } \\
\text { percentage }\end{array}$} \\
\hline Nagaland & 97.4 & $\begin{array}{l}\text { Telangana } \\
\text { Andhra }\end{array}$ & 61 & Manipur & 69.9 & Kerala & 97.9 & $\begin{array}{l}\text { Kerala } \\
\text { Himachal }\end{array}$ & 72.2 \\
\hline Manipur & 96.2 & Pradesh & 48 & $\begin{array}{l}\text { Odisha } \\
\text { Arunachal }\end{array}$ & 63.5 & Mizoram & 93.5 & Pradesh & 59.4 \\
\hline Mizoram & 96 & Manipur & 41 & Pradesh & 59.7 & $\begin{array}{l}\text { Goa } \\
\text { Himachal }\end{array}$ & 89 & Goa & 58.2 \\
\hline Sikkim & 95.3 & Chattisgarh & 37 & Bihar & 58.8 & Pradesh & 88.2 & $\begin{array}{l}\text { Punjab } \\
\text { Tamil }\end{array}$ & 55.1 \\
\hline Goa & 93.8 & Meghalaya & 36 & Telangana & 58.2 & Sikkim & 86.6 & Nadu & 50.9 \\
\hline Kerala & 92.1 & Tamil Nadu & 31 & Meghalaya & 57.3 & Manipur & 85 & Manipur & 45.9 \\
\hline
\end{tabular}

Source: NHFS 4, 2015-2016

\section{Conclusion}

The study finds an interesting Paradox that Manipur has outstanding health achievements despite being one of the poorest state ridden by ethnic crisis and insurgency. It certainly poses interesting questions on how such a poor state has impressive health outcomes. The paper makes an attempt to understand the Manipur`s health achievements with especial focus on women empowerment, by performing a comparative study across the states in India. It finds the women status in Manipur is relatively high in comparison to other states in India. Women in Manipur have higher autonomy in holding properties, higher work participation and higher household decision making power. Therefore, women empowerment seems to play an important role in determining the heath status of the state. Micro studies based on primary survey would be required in order to understand more about the association between women empowerment and health achievements in Manipur. Having said this, there is no denial of the importance of other important factors such as health care system or the role of state in relation to health achievements in the state.

\section{Notes}

i Quote by Manmohan Singh, while releasing Hunger and Malnutrition report 2011, can be found at http://pib.nic.in/newsite/erelease.aspx?relid=79457 


\section{International Journal of Social Science and Economic Research}

ISSN: $2455-8834$

Volume:06, Issue:07 "July 2021"

ii West Beangal and Telangana excluded, as data for per capita NSDP not available for 2014-15 in RBI Handbook of Statistics 2016-17.

iii Cited in Dreze and Sen, “An Uncertain Glory: India and its Contardictions” Penguin Allen Lane, London, 2013

iv Monica Das Gupta , "Public Health in India: Dangerous Neglect”EPW 2005, p. 5159

${ }^{v}$ Monica Das Gupta , "Public Health in India: Dangerous Neglect”'EPW 2005, p. 5159

${ }^{v i}$ Cited in Deepti Priya , "Burning Bright", Penguin Books India 2009, p. 45

vii Ghosh, Shukla and Ghosh G.K., "Women in Manipur”A.P.H. Publishing House New Delhi, 1997

viii Ghosh, Shukla and Ghosh G.K., "Women in Manipur”'A.P.H. Publishing House New Delhi, 1997, p.53

\section{Acknowledgement}

Notes: This paper is a part of my ongoing PhD work, currently pursuing at CESP, Jawaharlal Nehru University. I would like to thank my supervisor Professor Pradipta Chaudhury for his constant guidance and encouragement.

\section{References}

Berman, Peter; Ahuja, Rajeev and Bhandari (2010), "the Impoversihing Effect of Healthcare Payments in India: New Methodology and Findings", Economic and Political Weekly, April, Vol XLV(16): 65-71.

Berman, Peter (1998), "Rethinking Health Care Systems: Private Health Care Provision in India”, World Development, Vol. 26(8): 1463-1479.

Bhegum, Sharifa and Sen, Binayak (2009), "Maternal Health, Child Well Being and Chronic Poverty: Does Women`s Agency Matter?'. The Bangladesh Development Studies, December,Vol 32,(4): 69-93.

Biswas and kabir (2004), "Measuring Women's Empowerment: Indicators and measurement techniques". Social Change, September, Vol. 34(3):64-77.

Chaudhury, A; Bhuiya, Abbas; Chowdhury, Elahi; Rasheed, Sabrina, Hussain, Sabrina and Chen, Lincoln (2013), "The Bangladesh Paradox: Exceptional Health Achievement despite Economic Poverty”, Lancet, November, 382:1734-45.

Dreze, Jeane and Sen, Amartya (2013), "An Uncertain Glory: India and its Contradictions", Penguin, Allen Lane, London.

Dreze, Jeane and Sen, Amartya (2002), "India Development and Participation", Oxford. 
International Journal of Social Science and Economic Research

ISSN: 2455-8834

Volume:06, Issue:07 "July 2021"

Dharmalingam, A. and Morgan, Phillip, "Women's work, Autonomy, and Birth Control: Evidence from two South Indian Villages", Population Studies, July, Vol. 50(2): 187-201.

Dyson, Tim and Moore, Mick (1983), “ On Kinship Structure, Female Autonomy, and Demographic Behavior in India”, Population and Development Review, May, Vol. 9(1): 35-60

Gupta, Kamla and Yesudian, Princy (2006), “ Evidence of Women`s empowerment in India: a Study of Socio-Spatial Disparities”, GeoJournal, Vol. 65(4): 365-380.

Gupta, Monica Das (2005), "Public Health in India: Dangerous Neglect", Economic and Political Weekly, December, pp. 5159-5165.

Haque, Morshedul et al. (2011), "Women Empowerment or Autonomy: A comparative View in Bangladesh Context”, Bangladesh Journal of Sociology, July, Vol. 8 (2): 17-30.

Jejeebhoy, Shireen ( 1991), "Women`s Status and Fertility: Successive Cross-Sectional Evidence from Tamil Nadu, India, 1970-80", Studies in Family Planning, July-August, Vol. 22 (4): $217-$ 230 .

Kabeer, Naila (1999), “ Resources, Agency, Achievements: Reflections on the Measurement of women`s Empowerment”, Development and Change, May, Vol. 30, 435-464.

Kishor, Sunita and Gupta, Kamla (2004), "Women`s Empowerment and Its States: Evidence from the NFHS, Economic and Political Weekly, February, Vol. 39 (7) 14-20, pp. 697-712.

Ladusingh, Laishram and Pandey, Anamika (2013), “ The High Cost of Dying”, Economic and Political Weekly, March, Vol. XLVIII, 11: 44-49.

Malhotra, Anju; Schuler, Sidney and Boender Carol (2002), "Measuring Women`s Empowerment as a Variable in International Development", Background Paper for the World Bank Workshop on Poverty and Gender, June.

Mehrotra, Deepti Priya (2009), "Burning Bright: Irom Sharmila", Penguin Books India, New Delhi.

McDuie-Ra, Duncan (2015), "Violence against Women: North East", Critical Quest, NewDelhi.

National Family and Health Survey III Report, 2005-06.

Report of Expert Group to the review of methodology of measurement of poverty, 2014, June 
International Journal of Social Science and Economic Research

ISSN: 2455-8834

Volume:06, Issue:07 "July 2021"

Rifkin, Susan B. (2003), “ A Framework Linking Community Empowerment and Health Equity: It is a Matter of Chioce", Journal of Health, Population and Nutrition, September, Vol. 21 (3): 168-180.

Samuelson, Paul A. (1954), "The pure theory of Public Expenditure", The Review of Economic and Statics, November, Vol. 36 (4): 387-389.

Varky, Kureshi, Sarah and Lesnick, Timothy (2010),"Empowerment of women and its association with health of the community", Journal of Women Health, 72-77. 